\title{
ALCALASE CATALYZED PEPTIDE BOND FORMATION BETWEEN ASP AND D-ALA IN ANHYDROUS T-BUTANOL.
}

\author{
Shui-Tein Chen ${ }^{1}$, Sung-Yang Wu ${ }^{2}$, Shiah-Yun Chen $^{1}$, Kung-Tsung Wang ${ }^{1,2 *}$. \\ 1. Laboratory of Biocatalyst, Institute of Biological Chemistry, \\ Academia Sinica, P. O. Box 23-106, Taipei, Taiwan. 10098. \\ 2. Department of Chemistry, National Taiwan University.
}

Summary: Procedures for preparing precusors of the artificial sweetner, Moz-Asp(Bzl)D-Ala- $\mathrm{R}, \mathrm{R}=\mathrm{NH}_{2}, \mathrm{n}$-Propyl, isopropyl, in anhydrous t-butanol catalyzed by an industrial alkaline protease "alcalase" using a kinetic-controlled approach have been developed.

Introduction Recently, the search for proteases that are stable in organic solvents for peptide synthesis has been the subject of extensive investigation [Wong et al., 1990; Zhong et al., 1991, Schellenberger et al., 1991]. Several studies have demonstrated the possibility of using proteases to catalyse peptide synthesis in organic solvents [West et al., 1986; Kise et al., 1991; Stahl et al.,1990; Kuhl et al., 1991], but a drawback of those reactions is the lack of stability of the enzyme in organic solvents. Many immobilization processes have been developed to overcome this. This paper describes the use of an inexpensive enzyme, alcalase, as a catalyst for preparing precusors of the sweetner, MozAsp(Bzl)-D-Ala-NH ${ }_{2}$ [Bremner et al. 1986], Moz-Asp(Bzl)-D-Ala-OPro [Isowa et al, 1981], Moz-Asp(Bzl)-D-Ala-OPr, in anhydrous t-butanol using a kinetic-controlled approach.

"Alcalase" is a proteolytic enzyme prepared from a selective strain of Bacillus Licheniformis. The major enzyme component in alcalase is subtilisin Carlsberg (alkaline protease A), which is a serine protease widely used as an additive in detergents as a digesting enzyme. We have found that alcalase can maintain activity and stability in organic solvents [Chen et al., 1991; Chen et al, 1992]. Application of alcalase in organic synthesis has been limited, although it is a potent and inexpensive catalyst [Chen et al., 1986; Roper et al., 1983].

\footnotetext{
Abbreviation: Moz-, p-methoxybenzyloxycarbonyl- ; OBzl, benzyl ester; OPr ${ }^{n}$, n-propyl ester; $\mathrm{OPr}^{1}$, isopropyl ester.; Alcalase was purchased from NOVO industrial (Denmark) as a brown liquid with a specific activity of $2.5 \mathrm{AU} \cdot \mathrm{mL}^{-1}$. (According to NOVO, one Anson-unit (AU) is the amount of enzyme which, under standard conditions, digests haemoglobin al an initial rate liberating per min an amount of TCA-soluble product which gives the same color of phenol reagents as 1 mequiv of tyrosine. Thus, $1 \mathrm{AU}=1000 \mathrm{U}, 1 \mathrm{U}=1$ mmol of L-Tyr-OMe hydrolyzed per min.)
} 
The kinetically controlled synthesis catalysed by serine and cysteine proteases is widely used [Bender et al., 1964; Fastrez et al., 1973] since only short reaction times and low enzyme concentrations are required. Scheme 1 shows a typical scheme for this approach. In the presence of nucleophiles, an acyl-enzyme intermediate $[\mathrm{R}-\mathrm{C}(=\mathrm{O})-\mathrm{Ez}] \mathrm{can}$ be deacylated competitively by water or by amino-nucleophile $\left[: \mathrm{NH}_{2}-\mathrm{R} "\right]$. The yield of the reaction is determined by both the relative rate of hydrolysis and aminolysis, and the ratio of the concentration of each nucleophile (i.e., water and amine). Using t-butanol as the solvent in the reaction, the amino group is the only available nucleophile, and only peptide bond formation occurs.

\section{Scheme 1}
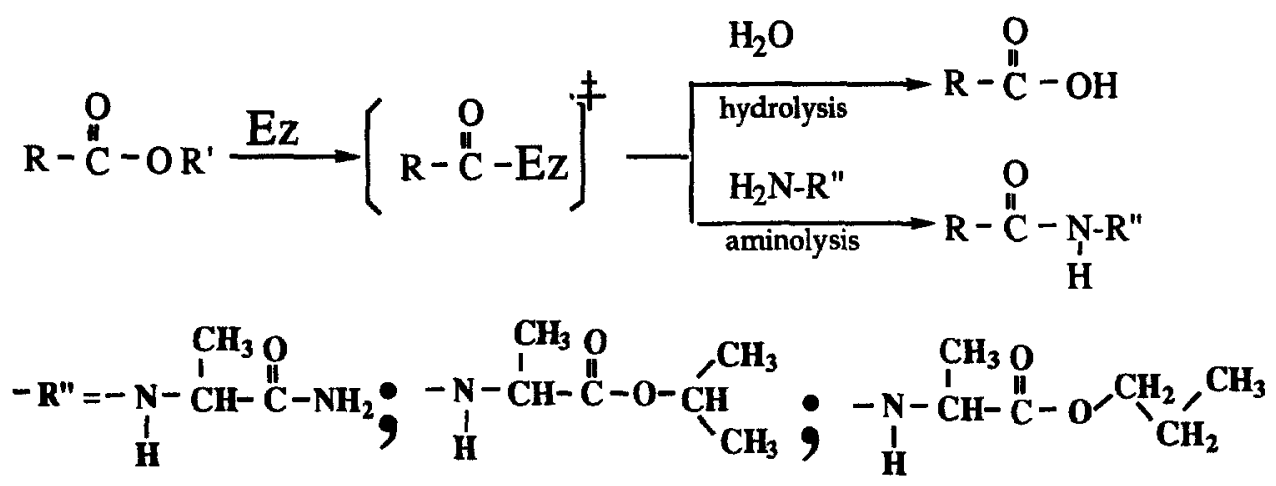

\section{Experimental}

Alcalase was purchased from NOVO industrial (Denmark) as a brown liquid with a specific activity of $2.5 \mathrm{AU} . \mathrm{mL}^{-1}$. The amino acids were purchased from Sigma USA. The substrates were prepared using the established method [Bodanszky, 1984]. Optical rotation was measured on a Universal Polarimeter (Schmidt \& Haensch, Germany). A Suntex P.C. 303 Auto-pH Controller was used (Suntex Instruments Co., Taiwan). Tic was performed on silica gel $\mathrm{G}$ pre-coated plates (E. Merck., Germany). Methanol, ethyl acetate, methylene chloride, acetonitrile, dioxane, ether, and acetone (hplc grade and reagent grade) were obtained from a local supplier, the ALPS Chem. Co. (Taiwan).

Preparation of alcalase solution. A typical procedure for removing water and contaminant from the alcalase solution was as follows: the enzyme solution $(5 \mathrm{~mL})$ was dialysized in phosphate buffer $\left(10 \mathrm{mM}, \mathrm{pH} 6.2\right.$, containing $\left.1 \% \mathrm{CaCl}_{2}\right)$ for 36 hours, the resulting solution was precipitated with $\mathrm{t}$-butanol $(50 \mathrm{~mL})$, the precipitate was suspended in anhydrous $t$-butanol by agitation, the resulting mixture was centrifuged $(5000 \mathrm{rpm})$ to separate the enzyme from the solvent, and the $t$-butanol was removed by decantation. The procedure of agitation and centrifugation was repeated several times, and the enzyme was then transferred to a reaction flask for further used.

\section{Enzymatic peptide bond formation. (Moz-Asp(Bzl)-D-Ala-OPr" as example)}

Moz-Asp(Bzl)-OBzl (10 mmol, 4.77g), D-Ala-Pr. $\mathrm{HCl}(30 \mathrm{mmol}, 5.03 \mathrm{~g})$, triethylamine $(30 \mathrm{mmol}, 4.2 \mathrm{~mL})$, and fresh-prepared alcalase $2.5 \mathrm{~L}$ ( $20 \mathrm{~mL}$, prewashed three times with $\mathrm{t}$-butanol) were added to anhydrous $\mathrm{t}$-butanol $(50 \mathrm{~mL})$. The mixture was shaken at $35^{\circ} \mathrm{C}$ for 2.5 hours. The resulting mixture was evaporated and then dissolved in ethyl acetate $(300 \mathrm{~mL})$ and washed with $0.5 \mathrm{~N} \mathrm{NaHCO}_{3}(3 \times 30 \mathrm{~mL}), 5 \%$ citric acid $(3 \times 30$ $\mathrm{mL})$, and water $(3 \times 30 \mathrm{~mL})$. After the organic solvent was evaporated under reduced pressure, Moz-Asp(Bzl)-D-Ala-OPr ${ }^{\mathrm{n}}$ was obtained as a white, amorphous solid (4.41 g, 88\%)

\section{Results and Discussion.}

The substrates were simply prepared using the established method.[Bodanszky, 
1984; Wunsch, 1974] The solubility of the substrates in t-butanol was high. Since water can compete with the amine nucleophile in kinetically controlled amide bond formation, the concentration of water in the reaction solution will affect the yield of the reaction (see scheme I). The water can be removed from the alcalase solution by repeated washing with anhydrous alcohol. A typical procedure for removing water from the alcalase solution was as follows: the enzyme solution was suspended in an anhydrous $t$-butanol by agitation, the resulting mixture was centrifuged to separate the enzyme from the solvent, and the t-butanol was removed by decantation. The procedure was repeated three times, and then the enzyme was transferred to a reaction flask for amide bond synthesis. Figure 1 shows the time courses for the alcalase catalyzed synthesis of Moz-Asp(Bzl)-D-Ala-NH ${ }_{2}$, Moz-Asp(Bzl)D-Ala-OPro ${ }^{n}$, and Moz-Asp(Bzl)-D-Ala-OPr in anhydrous t-butanol. The time course was monitored by hplc, and the initial reaction rate was determined from time-dependent plots of the increasing concentration of the product. The smallest amino acid derivative, $\mathrm{D}-\mathrm{Ala}-\mathrm{NH}_{2}$, formed the product more rapidly than did D-Ala-OPr and D-Ala-OPr ${ }^{\mathrm{n}}$. In a representative preparative scale reaction, alcalase $(20 \mathrm{~mL}, 5.0 \mathrm{AU}$, prewashed with $100 \mathrm{~mL}$ of $\mathrm{t}$-butanol for three times), acyl-donor (10 mmol), nucleophile $(30 \mathrm{mmol})$, and $\mathrm{t}$-butanol $(30 \mathrm{~mL})$ were stirred at $35^{\circ} \mathrm{C}$ until all the acyl-donors had been consumed (hplc, see table 1). The resulting solution was evaporated, to the reaction mixture was added ethyl acetate, and the resulting mixture was washed with $5 \%$ citric acid, $0.5 \mathrm{M} \mathrm{NaHCO}_{3}$, and then water. The organic solution was concentrated, and ether was added to it to precipitate the crude product. It was recrystallized with ethyl acetate/hexane (3:1) to give pure product. The results are summarized in table 1 . The physical properties of the products were confirmed by NMR, amino acid analysis of peptide hydrolysate, and their physical properties.

The entire preparative scale reaction was completed within 3 hours, and the yields ranged from $96 \%$ to $72 \%$. The shorter the reaction was, the higher was the yield. A small amount (3-8\%) of the hydrolysis by-product, Moz-Asp(Bzl)-OH, was observed during the

Figure 1 Time courses for alcalase catalyzed peptide bond formation in t-butanol. reaction as

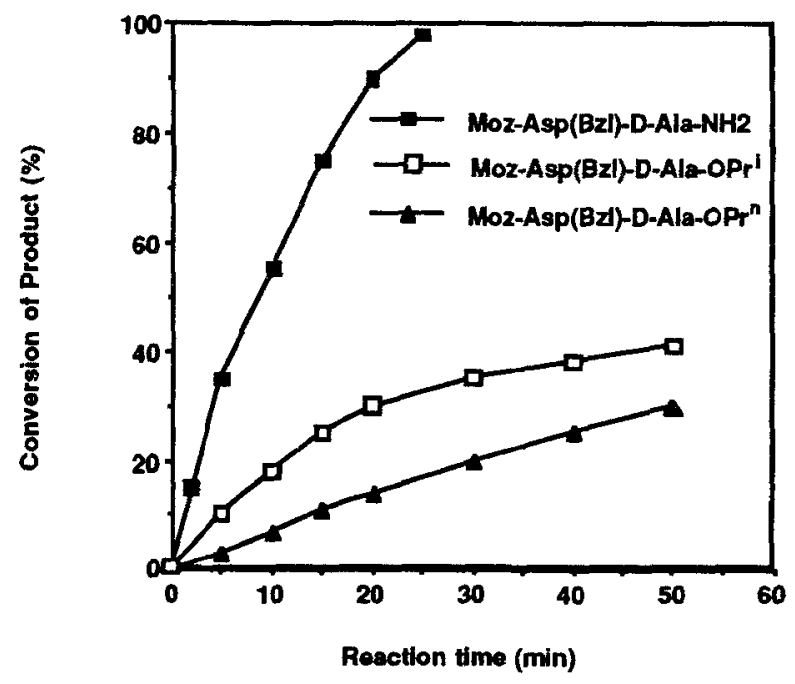

measured by hplc analysis of the reaction solution because of the water molecules associated with the enzyme that went into the reaction solution. 
Table 1. Alcalase catalyzed peptide bond formation in t-butanol.

\begin{tabular}{|c|c|c|c|c|c|}
\hline acyl donor & ucleophile & product & $\begin{array}{l}\text { yield } \\
\% \\
\end{array}$ & $\begin{array}{l}\mathrm{mp}: \\
{ }^{\circ} \mathrm{C}\end{array}$ & $\begin{array}{r}{[\alpha]_{\mathrm{D}}{ }^{25}:} \\
\mathrm{c} 1, \mathrm{MeOH}\end{array}$ \\
\hline Moz-Asp(Bzl)-Bzl & D-Ala-NH & Moz-Asp(Bzl)-D-Ala-NH ${ }_{2}(\mathbf{l})$ & 96 & $154-156$ & +11.88 \\
\hline$"$ & D-Ala-OPr" & Moz-Asp(Bzl)-D-Ala-OPrn (2) & 88 & $91-92$ & -0.95 \\
\hline " & D-Ala-OPri & Moz-Asp(Bzl)-D-Ala-OPr'(3) & 72 & $98.5-100$ & -0.05 \\
\hline
\end{tabular}

(1): 1-H nmr. d, 1.16 (t 3H), 2.64-2.79 (m 2H), 3.73 (s 3H), 4.15-4.26 (m 1H), 4.41-4.49 (m 2H), 4.94 (s 2H), 5.06 (m 2H), 6.88-7.33 (m 9H), 7.06 (s 2H), 7.60 (d 1H), 8.02 (d 1H). Fab mass, $\mathrm{MW}=457$, found $\mathrm{M}+1=458$.

(2): 1-H nmr. 0.80-0.88 (t 3H), 1.22-1.25 (d 3H), 149-1.60 (m 2H), 2.57-2.80 (m 2H), 3.72 (s 3H), 3.94-3.99 (t 2H), 4.16-4.23 (q 1H), 4.44-4.47 (m 1H), 4.93 (s 2H), 5.06 (s 2H), 6.87-7.33 (m 9H), 7.46-7.50 (d 1H), 8.29-8.33 (d 1H). Fab Mass $M W=500$, found $M+1=501$.

(3): 1-H nmr. d, 1.12-2.74 9 (m 6H), 1.20-1.24 (d 3H), 2.61-2.74 (m 2H), 3.73 (s 3H), 4.14 (q 1H), $4.93(\mathrm{~s} 2 \mathrm{H}), 5.07(\mathrm{~s} 2 \mathrm{H}), 4.82-5.029(\mathrm{~m} \mathrm{1H}), 6.87-7.33(\mathrm{~m} \mathrm{9H}), 7.47-7.51(\mathrm{~d} \mathrm{1H}), 8.26-8.30$ (d 1H). Fab Mass, $M W=500$, found $M+1=501$.

Application of an inexpensive industrial enzyme to synthesis the precusor of sweetners in anhydrous t-butanol has not been reported before. In conclusion, the alcalase-catalyzed amide formation was regioselective for the a-carboxyl of Glu residues. This new enzymatic process has several advantages: 1) the high turnover rate and low cost of the enzyme make enzyme immobilization unnecessary; 2) the enzyme is stable in alcoholic solvent, thus allowing operation at high substrate concentration; 3 ) the reaction is highly selective for ester hydrolysis, and the peptide bonds remain intact; and 4) the substrate preparation and product isolation are simple.

\section{References:}

Bender, M.L., Clement, G. E., Gunter, C. R., Kezdy, F. J., (1964) J. Amer. Chem. Soc. 86, 3097.;

Bodanszky, M., "Principle of Peptide Synthesis", Springer-Verlag, Berlin, 1984.

Bremner, D., (1986) Chemistry in Britain, Jan. 11.

Chen, S. T., Wang, K. T., Wong, C. H., (1986) Chem. Commu. 1514-1516.

Chen, S. T., Hsiao, S. C., Wang, K. T., (1991) Bioorg. \& Med. Chem.

Letters. 1(9), 445.

Chen, S. T., Chen, S. Y., Wang, K. T., (1992) J. Org. Chem. 57, 6960-6965.

Fastrez, J., Fersht, A. R., (1973) Biochem. 12, 2025.

Kise, H., Tomiuchi, Y., (1991) Biotech. Letters 13, 317-322.

Kuhl, P., Halling, P.J., Jakubke, H.D.,(1990) Tetrahydron Letters 31, 5213-5216.

Roper, J. M., Bauer, D. P., (1983) Synthesis, 1041-1042.

Schellenberger, V., Jakubke, H. D., (1991) Angew Chem, Int. Ed. Engl. 30, 1437-1449.

Stahl, M., Mansson, M. O., Mosbach, K., (1990) Biotech. Letters 12(3), 161-166.

Takemoto, T., Hijiya, T., Yukawa, T., (1986) Peptide Chemistry, 247-250.

Miyazawa, T., (Ed.) Protein Research Fouddation, Osaka (1987).

West, J. B., Wong, C. H., (1986) Chem. Commun. 417-418.

Wunsch, E. (1974) Houben-Weyl, Vol. XV/1 and XV/2, Georg Thieme Verlag, Stuttgart. Wong, C. H., Chen, S. T.; Hennen, W. J., Bibbs, J. A., Wang,Y. F., Liu, J. L. C., Pantoliano, M. W., Whitlow, M., Bryan, P. N., (1990) J. Amer. Chem. Soc. 112, 945. Zhong, Z., Liu, J. J.C., Dinterman, L. M., Finkelman, M. A.J., Mueller, T. W., Rollence, M. L., Whitlow, M., Wong, C. H., (1991) J. Amer. Chem. Soc. 113, 683. 